\title{
PENGARUH STRUKTUR AKTIVA (ASSETS STRUCTURE), RETURN ON ASSETS DAN PERTUMBUHAN PENJUALAN (GROWTH OF SALES) TERHADAP STRUKTUR MODAL (CAPITAL STRUCTURE) PADA PERUSAHAAN PROPERTY DAN REAL ESTATE DI BURSA EFEK INDONESIA TAHUN 2011 - 2015
}

\author{
Annie Chandra ${ }^{1}$, Wenny Tantoni ${ }^{2}$, Windy Villany ${ }^{3}$, Mahmuddin Syah Lubis ${ }^{4}$, Faisal Akbar $^{5}$ \\ ${ }^{1,2,3,4,5}$ Prodi Akuntansi, Fakultas Ekonomi, Universitas Prima Indonesia, Jalan Belanga No. 1 Simp. Ayahanda, \\ Medan, Sumatera Utara, 20118, Indonesia \\ E-mail : annie.chandra@hotmail.com
}

\begin{abstract}
The purpose of the research is to know and analyze the effect of Assets Structure, Return On Assets (ROA) and Growth of Sales on Debt Equity ratio. The research used some theories relating to Assets Structure, Return On Assets, Growth of Sales and Capital Structure. The research approach of this research was quantitative. This type of research is descriptive explanatory. The populations in this research are 53 companies of Property and Real Estate in the Indonesia Stock Exchange in the year of 2011-2015. The result of the research samples were 25 companies of Property and Real Estate in the Indonesia Stock Exchange in the year of 2011-2015. The result of the research as well as a conclusion from this research stated that partially Assets Structure had a negative significant effect on Capital Structure, Partially ROA and Growth of Sales did not have a significant effect on Capital Structure. Simultaneously, Assets Structure, Return On Assets and Growth of Sales had a significant effect on Capital Structure.
\end{abstract}

Keyword: Assets Structure, Return On Assets, Growth of Sales, Debt to Equity Ratio

\section{PENDAHULUAN}

Dalam menjalankan suatu perusahaan tentu membutuhkan dana yang sangat besar, sehingga modal merupakan hal yang sangat penting bagi perusahaan. Kebutuhan akan dana tidak dapat sepenuhnya dipenuhi dengan menggunakan modal sendiri. Oleh karena itu, perusahaan melakukan pemenuhan dana dari pihak lain atau melakukan penundaan pembayaran beberapa kewajiban. Pemenuhan dana dapat dilakukan dengan cara pinjaman, utang dan memasuki pasar modal. Dana yang diperoleh dari pasar modal dapat digunakan untuk pengembangan usaha, ekspansi, penambahan modal kerja dan lain-lain. Bisnis Property dan real estate adalah bisnis yang diperkirakan akan berkembang pesat dimasa depan. Bisnis di bidang property ini dapat menghasilkan keuntungan yang sangat besar. Tidak hanya itu, bisnis properti ini marak karena keinginan masyarakat untuk berinvestasi. Dewasa ini property merupakan salah satu kebutuhan utama yang harus dimiliki setiap orang, hal inilah yang menjadi alasan utama mengapa pembangunan perumahan semakin tinggi.

Struktur Modal (Capital Structure) merupakan penentuan seberapa besar kemampuan perusahaan membayar utang dengan modal yang dimilikinya. Tujuan utama dari struktur modal yaitu membuat komposisi sumber pembiayaan yang paling optimal. Assets Structure ialah rasio perimbangan antara aset tetap dan total aset untuk mengetahui besarnnya anggaran yang dianggarkan untuk tiap komponen aktiva dan merupakan bentuk dari pemodalan perusahaan. Return On Assets (ROA) merupakan perhitungan untuk mengetahui berapa keuntungan yang didapatkan dengan memanfaatkan aset yang ada didalam perusahaan.. Nilai ROA yang semakin besar menunjukan kinerja perusahaan yang baik dan juga menjadi bahan pertimbangan para penanam modal untuk memberikan bantuan berupa tambahan dana. Growth of Sales ialah perhitungan dalam membandingkan antara penjualan sekarang dan lalu. 
Jika penjualan meningkat dibandingkan dengan tahun sebelumnya, ini menunjukan aktivitas penjualan perusahaan yang berjalan dengan baik. Suatu perusahaan yang penjualannya stabil akan lebih mudah memperoleh pinjaman daripada perusahaan yang tidak stabil, Jika penjualan barang atau jasa berjalan dengan baik, perusahaan akan mendapatkan lebih banyak keuntungan, akan dapat membiayai pengeluaran untuk pemasaran yang lebih luas, serta mampu menyokong lebih banyak dana untuk siklus selanjutnya dari keseluruhan proses.

\section{TINJAUAN PUSTAKA}

Struktur Aktiva. Struktur Aset adalah hasil ekonomi yang merupakan milik dari perusahaan yang dapat dijadikan agunan. (Atmaja 2008). Struktur aktiva adalah aset atau harta yang dimiliki perusahaan yang berperan dalam operasi perusahaan (Harahap 2013). Struktur kekayaan merupakan suatu rasio yang dapat dicari dengan membagi aktiva tetap dengan total kekayaan perusahaan (Riyanto 2008).

$$
\text { Struktur Aktiva }=\frac{\text { Aktiva Tetap }}{\text { Total Aset }}
$$

Return On Assets. Return on Asset adalah rasio untuk mengukur kemampuan perusahaan dalam memanfaatkan aktivanya untuk memperoleh laba (Prastowo 2014). Return on Assets merupakan rasio yang menunjukkan hasil (return) atas penggunaan aset perusahaan dalam menciptakan laba bersih (Hery 2015). ROA ialah suatu penilaian kapasitas suatu perusahaan secara menyeluruh dalam mendatangkan laba dengan jumlah keseluruhan kekayaan yang terdapat dalam perusahaan.(Syamsuddin 2015)

$$
\text { Hasil Pengembalian atas Aset }=\frac{\text { Laba Bersih }}{\text { Total Aset }}
$$

Pertumbuhan Penjualan. Pertumbuhan penjualan merupakan rasio yang menggambarkan kemampuan perusahaan dalam mempertahankan posisi ekonominya di tengah pertumbuhan perekonomian dan sektor usahanya. (Kasmir 2012). Penjualan merupakan total jumlah yang dibebankan kepada pelanggan atas barang yang dijual perusahaan, baik penjualan tunai maupun penjualan kredit. (Hery 2015). Pertumbuhan penjualan ialah rasio yang digunakan untuk mengukur kapasitas perusahaan untuk dapat mempertahankan kedudukannya. (Sugiono \& Untung 2016)

$$
\text { Kenaikan Penjualan }=\frac{\text { Penjualan Tahun Ini }- \text { Penjualan Tahun Lalu }}{\text { Total Aset }}
$$

Struktur Modal. Struktur modal yaitu proporsi untuk menentukan keperluan belanja suatu instansi atau perusahaan (Rodoni \& Ali 2014). struktur modal merupakan rasio yang menunjukkan beberapa bagian dari setiap rupiah modal sendiri yang dijadikan jaminan utang. (Jumingan 2014). Rasio Utang terhadap modal sendiri atau DER ialah salah satu formula yang digunakan untuk menghitung Struktur Modal (Sitanggang 2013).

$$
\text { Debt to Equity Ratio }=\frac{\text { Total Utang }}{\text { Modal Sendiri }}
$$


Struktur Aktiva Terhadap Struktur Modal. Perusahaan dengan aset berwujud yang besar akan lebih cenderung untuk menggunakan hutang yang lebih besar daripada perusahaan yang aset berwujudnya kecil. (Sartono 2010). Perusahaan yang memiliki Aktiva tetap yang besar dapat mendapatkan pinjaman yang banyak dikarenakan aktiva tetap perusahaan tersebut dapat dijadikan sebagai jaminan. (Kamaludin 2011). Perusahaan yang memiliki komposisi aktiva tetap berwujud yang lebih besar, tentu akan mempunyai peluang untuk memperoleh tambahan modal dengan utang karena aktiva tetap tersebut dapat dijadikan sebagai angunan. (Sitanggang 2013).

$H_{1}$ : Struktur Aktiva berpengaruh positif signifikan terhadap Struktur Modal

Return On Assets Terhadap Struktur Modal. Perusahaan yang menggunakan utang dalam skala kecil dikarenakan memiliki pendapatan yang tinggi (Atmaja 2008). Dengan laba ditahan yang besar, perusahaan akan lebih senang menggunakan laba ditahan sebelum menggunakan hutang (Sartono 2010). Profit perusahaan pada periode lalu sangatlah penting untuk memastikan struktur modal pada tahun kemudian. Perusahaan yang memiliki pemasukan atau pendapatan yang tinggi akan lebih memilih untuk menggunakan laba ditahan daripada hutang untuk pembiayaan operasinal perushaan. (Kamaludin 2011)

$\mathrm{H}_{2}$ : Return On Assets berpengaruh positif signifikan terhadap Struktur Modal

Pertumbuhan penjualan terhadap struktur modal. Penjualan yang stabil menggunakan struktur modal yang lebih besar. (Riyanto 2008). Suatu perusahaan yang penjualannya berjalan konstan dan solid akan cenderung mudah mendapatkan bantuan (Kamaludin, 2011).

$\mathrm{H}_{3}$ : Pertumbuhan Penjualan berpengaruh signifikan terhadap Struktur Modal

\section{METODE PENELITIAN}

Pengukuran dan Defenisi Operasional. Dalam penelitian ini yang berperan sebagai variabel (Y) atau dependen adalah Struktur Modal sedangkan Variabel (X) atau independen dalam penelitian ini adalah :

a. Struktur Aktiva (X1). Perimbangan antara kekayaan tetap suatu perusahaan dan total kekayaannya untuk mengetahui besar alokasi dana tiap komponen aktiva.

b. Return On Assets (X2). Return On Assets (ROA) merupakan perhitungan untuk mengetahui berapa keuntungan yang didapatkan dengan memanfaatkan aset yang ada didalam perusahaan.

c. Pertumbuhan Penjualan (X3). Kenaikan Penjualan (Growth of Sales) yaitu suatu rasio yang mengukur tingkat penjualan tahun berjalan dengan yang lalu.

Metode Analisis Data. Jenis penelitian ini menggunakan pendekatan kuantitatif, bertujuan untuk meneliti populasi atau sampel tertentu. Data yang dipakai pada penelitian ini adalah data sekunder berupa laporan keuangan (financial report) pada perusahaan property dan real estate di Bursa Efek Indonesia tahun 2011-2015. Populasi penelitian ini merupakan seluruh perusahaan bidang properti dan realestate yang dilisting di BEI tahun 2011-2015. Pengambilan sample menggunakan purposive sampling dengan kriteria dibawah ini:

1. Perusahaan property dan realestate di BEI tahun 2011-2015.

2. Perusahaan property dan realestate yang mempublikasikan laporan keuangan berturutturut dan tidak melakukan merger tahun 2011-2015.

3. Perusahaan property dan real estate yang tidak menghadapi kerugian tahun 2011-2015

Sampel pada penelitian ini diperoleh dari perhitungan berikut ini: 
Tabel 1. Purposive Sampling

\begin{tabular}{clc}
\hline No. & \multicolumn{1}{c}{ Kriteria } & $\begin{array}{c}\text { Jumlah } \\
\text { Sampel }\end{array}$ \\
\hline 1. & $\begin{array}{l}\text { Perusahaan property dan realestate di BEI tahun 2011- 2015 } \\
\text { 2. }\end{array}$ & $\begin{array}{l}\text { Perusahaan property dan realestate yang tidak mempublikasikan laporan } \\
\text { keuangan berturut-turut dan melakukan merger tahun 2011-2015 }\end{array}$ \\
$\begin{array}{l}\text { 3. } \begin{array}{l}\text { Perusahaan property dan realestate yang menghadapi kerugian tahun } \\
\text { 2011-2015 }\end{array} \\
\text { Jumlah perusahaan yang terpilih menjadi sampel penelitian }\end{array}$ & $(12)$ \\
\hline
\end{tabular}

Penelitian ini menggunakan Struktur Modal sebagai variabel dependen, dan variabel independen terdiri atas 3 variabel yaitu Struktur Aktiva, Return On Assets dan Pertumbuhan Penjualan. Teknik penguraian yang digunakan adalah regresi linier berganda. Statistical Package for Social Science (SPSS) digunakan dalam melakukan uji statistik penelitian ini. Adapun model dari penelitian ini adalah sebagai berikut:

$$
\mathrm{Y}=\mathrm{a}+\mathrm{b}_{1} \mathrm{X}_{1}+\mathrm{b}_{2} \mathrm{X}_{2}+\mathrm{b}_{3} \mathrm{X}_{3}+\mathrm{e}
$$

Dimana:

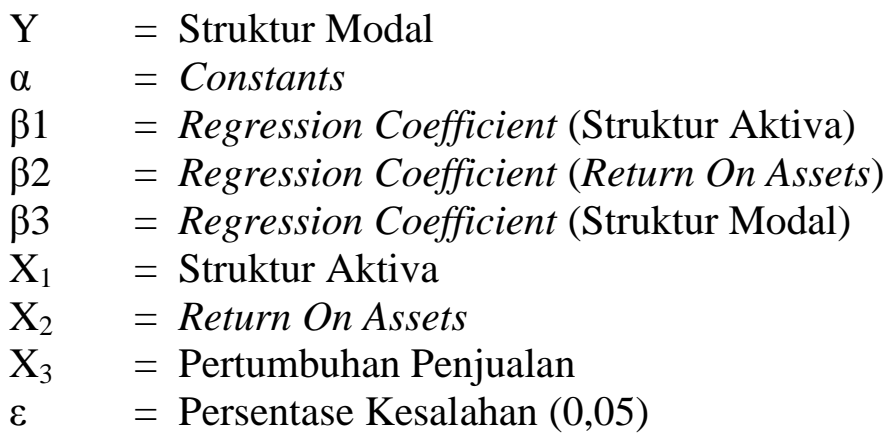

Adapun untuk mendapatkan hasil yang lebih akurat, maka dilakukan:

1. Uji Asumsi Klasik

a. Uji Normalitas. Tujuan menggunakan uji ini yaitu untuk memahami model regresi berdistribusi normal ataupun tidak. Uji Normalitas ini dapat dilakukan dengan Uji Grafik dan Uji Statistik. Uji grafik dapat dilakukan dengan melihat Grafik Histogram dan P-Plot, sedangkan Statistik dapat dilihat dengan Uji Sampel K-S.

b. Uji Multikolinieritas. Uji ini memiliki tujuan untuk memahami apakah model regresi mempunyai hubungan dengan variabel independen. Variabel Independen yang tidak memiliki hubungan atau korelasi sesama variabel independen merupakan model regresi yang baik. Untuk mendeteksi ada tidaknya multikolinieritas dapat dilakukan dengan melihat nilai VIF $\leq 10$ maka tidak terdapat multikolinearitas dan Tolerance $\geq$ 0,10 juga tidak terdapat multikolinearitas.

c. Uji Autokorelasi. Autokorelasi ialah suatu pengujian untuk menguji apakah dalam model regresi linear terdapat hubungan antara kesalahan pengganggu pada periode berjalan dengan kesalahan pengganggu pada periode sebelumnya. Pengujian Autokorelasi dapat dideteksi menggunakan Durbin-Watson. Statistik hipotesis yang akan diuji adalah:

$\mathrm{H}_{0}$ : Tidak ada autokorelasi $(\mathrm{r}=0)$

$\mathrm{H}_{1}$ : Ada autokorelasi $(\mathrm{r} \neq 0)$

Kriteria Durbin-Watson dapat dilihat dari tabel berikut ini: 
Tabel 2. Kriteria Durbin Watson

\begin{tabular}{ccc}
\hline Hipotesis (0) & Pertimbangan & Ketentuan \\
\hline Tidak ada autocorrelation $(+)$ & Rejected & $0<\mathrm{dw}<\mathrm{dL}$ \\
Tidak ada autocorrelation $(+)$ & No decision & $\mathrm{dL} \leq \mathrm{dw} \leq \mathrm{dU}$ \\
Tidak ada korelasi $(-)$ & Rejected & $4-\mathrm{dL}<\mathrm{dw}<4$ \\
Tidak ada korelasi $(-)$ & No decision & $4-\mathrm{dU} \leq \mathrm{dw} \leq 4-\mathrm{dL}$ \\
Tidak ada autocorrelation, $(+)$ atau $(-)$ & No Rejected & $\mathrm{dU}<\mathrm{dw}<4-\mathrm{dU}$ \\
\hline
\end{tabular}

Sumber : Ghozali (2016)

d. Uji Heteroskedastisitas. Uji heteroskedastisitas adalah pengujian untuk melihat apakah terjadi ketidaksamaan varians dari residual suatu pengamatan dengan yang lainnya. Tidak terjadi heteroskedastisitas merupakan model regresi yang baik. Uji ini dapat dilakukan dengan uji scatterplot dan uji glejser. Dalam Uji Scatterplot dan Glejser, jika titik-titik data mengumpal pada satu tempat dan nilai sig $<0.05$ merupakan pertanda bahwa telah terjadi heterokedastisitas, Jika penyebaran titik data tidak mengumpal dan nilai sig $>0.05$ tersebar secara acak maka tidak terjadi heterokedastisitas.

2. Regresi Linier Berganda. Hubungan linier antara satu ataupun lebih variabel independen dengan satu (1) variabel dependen dapat dianalisis menggunakan analisis linier berganda.

3. Uji Hipotesis, yang terdiri dari :

a. Parsial ( $t$ ). Uji parsial ialah uji untuk melihat hubungan per satu variabel $\mathrm{X}$ dengan $\mathrm{Y}$.

b. Simultan $(F)$. Uji Simultan ialah uji menunjukkan apakah seluruh variabel $\mathrm{X}$ yang digunakan dalam model mempunyai pengaruh secara beriringan terhadap variabel terikat.

\section{HASIL ANALISIS DAN PEMBAHASAN}

\subsection{Hasil Analisis}

Statistik Deskriptif. Statistik deskriptif merupakan suatu gambaran perihal nilai terkecil atau minimum, nilai terbesar atau maksimum, nilai average dan standard deviation data. Tabel dibawah ini merupakan tampilan data statistik dari variabel yang digunakan dalam penelitian ini.

Tabel 3. Statistik Deskriptif

\begin{tabular}{clrrrr}
\hline & N & Minimum & Maximum & Mean & Std. Deviation \\
\hline SA & 125 & 0.136 & 0.948 & 0.56909 & 0.219980 \\
ROA & 125 & 0.002 & 0.316 & 0.07365 & 0.050314 \\
PP & 125 & -0.990 & 4.052 & 0.30141 & 0.622908 \\
SM & 125 & 0.002 & 2.849 & 0.86249 & 0.506375 \\
Valid N (listwise) & 125 & & & & \\
\hline \multicolumn{5}{l}{ Sumber: Hasil data yang diolah (SPSS 2018) }
\end{tabular}

Tabel 3 menunjukkan bahwa hasil data statistik deskriptif dengan nilai minimum, nilai maksimum, nilai rata-rata (mean) dan standar deviasi (simpangan baku) dari variabel $\mathrm{X}_{1}, \mathrm{X}_{2}, \mathrm{X}_{3}$ dan Y. Dari tabel di atas diperoleh bahwa:

1. Struktur Aktiva dengan 125 sampel . Nilai rata-rata Struktur Aktiva adalah 0.56909 dengan standar deviasi 0.219980. Nilai min 0.136 yang diperoleh PT. Perdana Gapura (2015), sedangkan maksimumnya 0.948 di PT. Roda Vivatex Tbk (2013). 
2. Return On Assets dengan 125 sampel. Nilai rata-rata Return On Assets adalah 0.07365 dengan standar deviasi 0.050314. Nilai min 0.002 diperoleh PT. Megapolitan Development (2011), sedangkan nilai maks 0.316 jatuh pada PT. Danayasa Arthatama (2013).

3. Pertumbuhan Penjualan dengan 125 sampel. Nilai rata-rata Pertumbuhan Penjualan adalah 0.30141 dengan standar deviasi 0.622908. Nilai min -0.990 diperoleh PT. Alam Sutera Reality (2011) sedangkan nilai maks 4.05 yang terdapat pada PT. MNC Land (2012)

\section{Hasil Uji Asumsi Klasik}

1. Uji Normalitas. Uji memiliki tujuan untuk memeriksa apakah suatu model regresi data berdistribusi normal atau tidak yang dilakukan dengan analisis grafik dan statistik. Deteksi normalitasdengan melihat penyebaran titik pada sumbu diagonal dari grafik, dengan syarat:

1. Jika titik menyebar disekitar dan mengikuti arah garis diagonal, maka model regresi berdistribusi normal.

2. Jika data menyebar jauh atau tidak mengikuti arah garis diagonal, maka model regresi tidak berdistribusi normal.

Uji Normalitas dilakukan dengan dua cara yaitu analisis statistik dan analisis grafik. Pada analisis statistik digunakan Kolmogrov-Smirnov sedangkan pada penelitian analisis grafik yang digunakan adalah histogram dan normal P-Plot. Data dianggap normal apabila nilai signifikansi yang diperoleh lebih besar atau sama dengan $\alpha$ dimana nilai $\alpha$ adalah 5\%. Hasil dari uji normalitas ialah sebagai berikut:

Tabel 4. Uji Normalitas $K-S$

\begin{tabular}{llr}
\hline & & Unstrd Residual \\
\hline N & & 125 \\
& Mean & 0.0000000 \\
Most Extreme Differences & Std. Deviation & 0.48514058 \\
& Absolute & 0.121 \\
& Positive & 0.121 \\
Kolmogorov-Smirnov Z & Negative & -0.076 \\
Asymp. Sig. (2-tailed) & & 1.354 \\
a. Test distribution is Normal. & & 0.051 \\
b. Calculated from data. & & \\
\hline Sumber: $:$ Hasil Data yaneter & & \\
\hline
\end{tabular}

Sumber : Hasil Data yang diolah (SPSS 2018)

Tabel 4 menunjukkan bahwa nilai $K-S$ sebesar 1,354 dan nilai Asymp.Sig. (2-tailed) > 0,05 yaitu sebesar 0,051 , sehingga model memiliki residual yang terdistribusi normal 


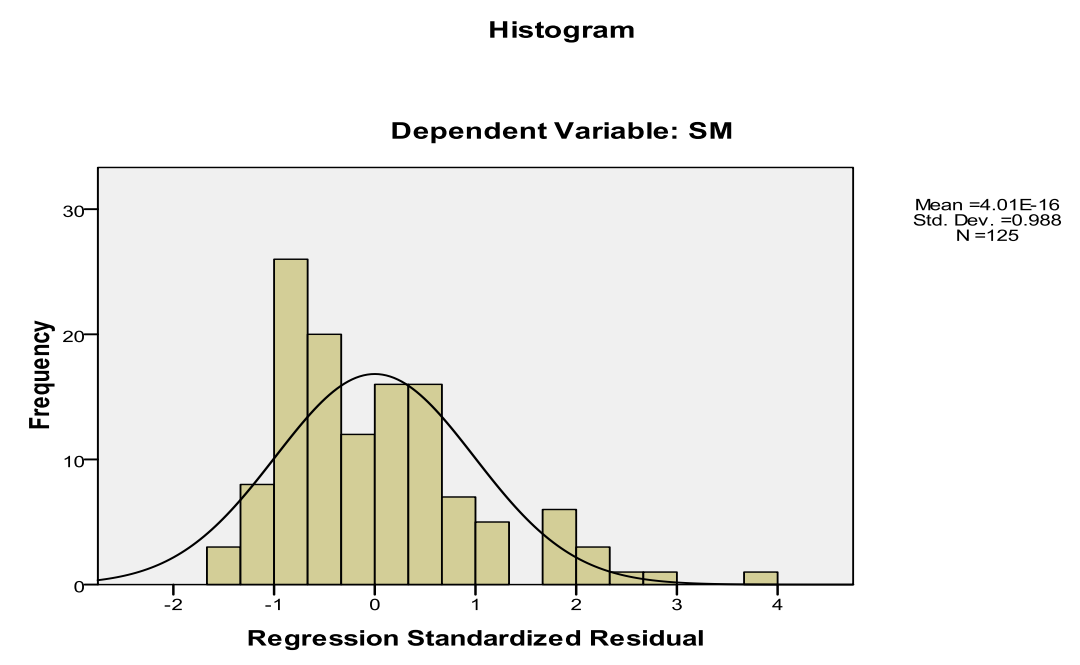

Sumber : Hasil Data yang diolah (SPSS 2018)

Dari grafik histogram dapat dilihat bahwa histogram sebagian besar tampak mengikuti kurva normal, sehingga dapat dikatakan bahwa sebaran data tersebut berdistribusi normal. Begitu pula dengan hasil uji normalitas menggunakan grafik normal p-plot sebagai berikut:

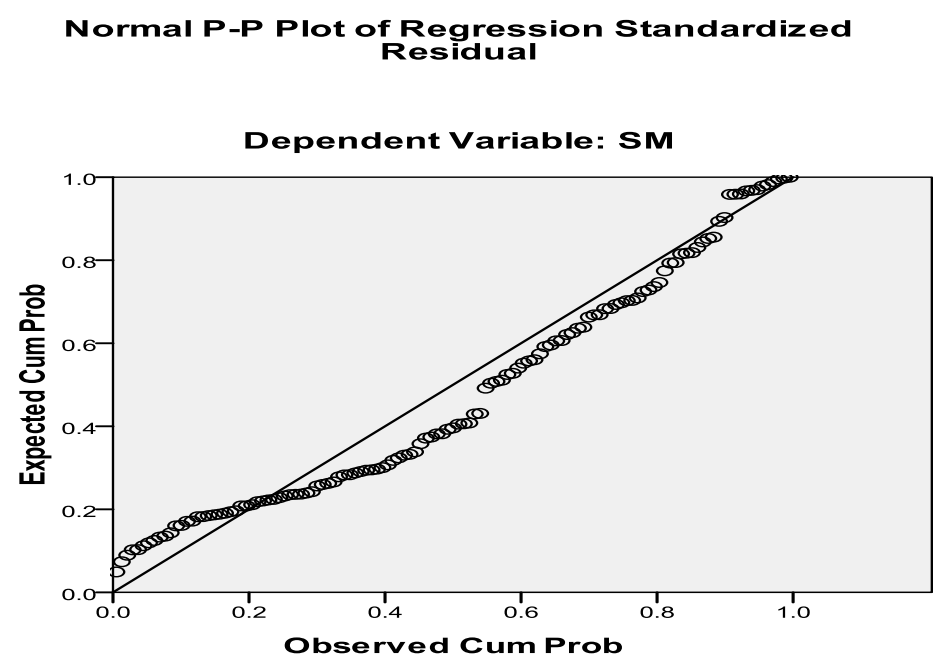

Sumber : Hasil data yang diolah (SPSS 2018)

Dari grafik P-Plot terlihat titik-titik menyebar mendekati garis diagonal sehingga dapat dikatakan data berdistribusi normal.

2. Uji Multikolinieritas. Uji ini memiliki tujuan untuk menguji apakah ditemukannya hubungan antar variabel bebas. Tidak terjadinya korelasi antara variabel independen merupakan model regresi yang baik. Ada dan Tidak terjadinya multikolonieritas dapat diketahui dari nilai (1) Tolerance (2) VIF. Untuk menunjukkan adanya multikolonieritas adalah nilai Tolerance lebih besar dari 0.10 dan nilai VIF lebih kecil dari 10. Hasil uji dapat dilihat pada tabel 5 . berikut: 
Tabel 5. Hasil Uji Multikolinieritas

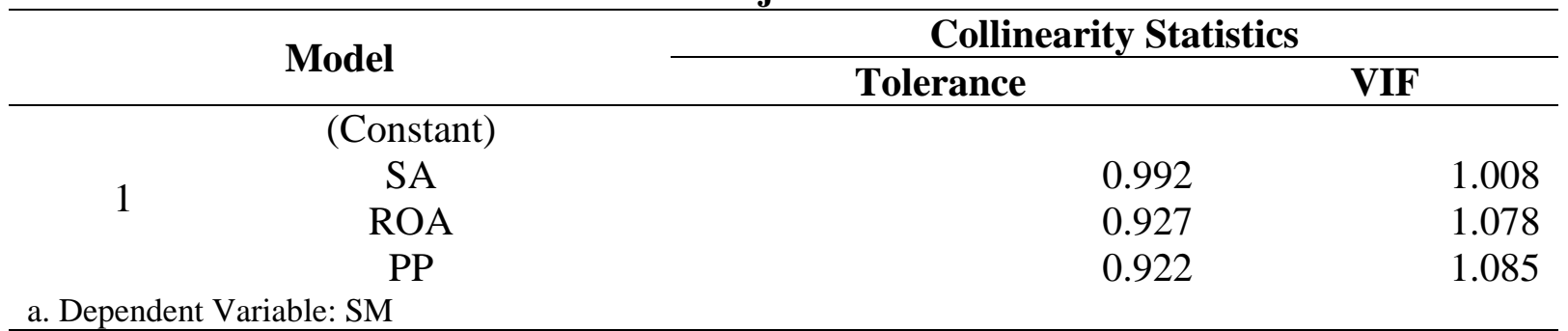

Sumber : Hasil Data yang diolah (SPSS 2018)

Tabel 4 menunjukkan bahwa, nilai tolerance Struktur Aktiva $0.992>0.10$, dengan nilai VIF $1.008<10$, nilai tolerance Return On Assets $0.927>0.10$, dengan nilai VIF $1.078<$ 10, nilai tolerance Pertumbuhan Penjualan $0.922>0.974$ dengan nilai VIF $1.085<10$. Sehingga dapat disimpulkan tidak adanya Multikolonieritas.

3. Uji Autokorelasi. Dalam Autokorelasi, kita dapat menggunakan DW untuk melihat apakah adanya terjadi autkorelasi atau tidak. Hasil dari Autokorelasi dapat dilihat sebagai berikut:

Tabel 6. Uji Autokorelasi Durbin-Watson

\begin{tabular}{lccccc}
\hline Model & R & R Square & $\begin{array}{c}\text { Adjusted R } \\
\text { Square }\end{array}$ & $\begin{array}{c}\text { Std. Error of the } \\
\text { Estimate }\end{array}$ & Durbin-Watson \\
\hline 1 & $0.287^{\text {a }}$ & 0.082 & 0.059 & 0.491118 & 1.827 \\
$\begin{array}{l}\text { a.Predictors: (Constant), PP, ROA, SA } \\
\text { b.Dependent Variable: SM }\end{array}$ & & & & \\
\hline
\end{tabular}

Sumber: Hasil Data yang diolah (SPSS 2018)

Tabel 6 menunjukkan bahwa, nilai Durbin Watson (DW) adalah 1.827, nilai ini dibandingkan dengan nilai table signifikan 5\%, jumlah sampel $\mathrm{N}=125$ dan jumlah variabel independen $3(\mathrm{~K}=3)$ maka didapatkan $\mathrm{dL}=1,6592$ dan $\mathrm{dU}=1,7574$. Dengan melihat kriteria pedoman Durbin Watson keputusan baik harus memenuhi syarat dU < DW $<4-$ dU. Hasil yang didapatkan adalah 1,7574 $<1,827<4-1,827$ maka dapat disimpulkan bahwa tidak ada autokorelasi positif atau negatif atau dapat disimpulkan tidak terdapat autokorelasi.

4. Uji Heteroskedastisitas. Uji heteroskedastisitas ialah untuk menguji apakah dalam regresi terjadi perbedaan varians dari pengamatan satu ke lainnya.

Uji Scatterplot. Uji grafik Scatterplot hasil dari uji heteroskedastisitas dapat ditunjukkan dalam grafik scatterplot antara ZPRED dan SRESID seperti yang terlihat pada gambar berikut: 


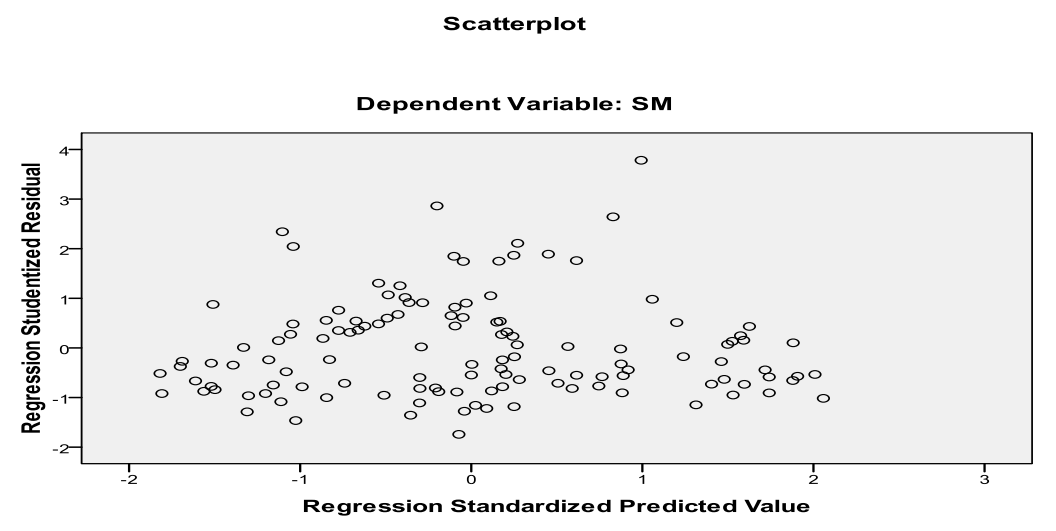

Gambar 3. Uji Scatterplot

Sumber : Hasil Data yang diolah (SPSS 2018)

Bedasarkan Gambar 3 dapat dilihat bahwa titik-titik menyebar secara acak baik diatas maupun dibawah angka nol (0) pada sumbu Y, tidak berkumpul disatu tempat, sehingga dari grafik Scatterplot dapat diketahui tidak ada terjadinya heteroskedastisitas.

Uji Glejser. Uji Glejser dilakukan dengan meregres nilai absolute terhadap variabel independen. Bila variabel dependen mempengaruhi variabel independen secara statistik, pertanda bahwa adanya indikasi terjadi heteroskedastisitas.

Tabel 7. Uji Glejser

\begin{tabular}{|c|c|c|c|c|c|c|}
\hline & \multirow[t]{2}{*}{ Model } & \multicolumn{2}{|c|}{ Unstandardized Coefficients } & \multirow{2}{*}{$\begin{array}{c}\text { Standardized Coefficients } \\
\text { Beta }\end{array}$} & \multirow[t]{2}{*}{$\mathbf{t}$} & \multirow[t]{2}{*}{ Sig. } \\
\hline & & $\mathbf{B}$ & Std. Error & & & \\
\hline 1 & (Constant) & 0.344 & 0.083 & & 4.163 & 0.000 \\
\hline & SA & 0.032 & 0.122 & 0.024 & 0.264 & 0.792 \\
\hline & ROA & 0.370 & 0.553 & 0.063 & 0.669 & 0.505 \\
\hline & PP & -0.021 & 0.045 & -0.044 & -0.465 & 0.643 \\
\hline
\end{tabular}

Sumber: Hasil data yang diolah (SPSS 2018)

Tabel 7 menunjukkan bahwa nilai signifikan struktur aktiva, return on assets dan pertumbuhan penjualan diatas 0.05 yang berarti tidak terjadi heteroskedastisitas.

Model Penelitian. Model analisis dalam penelitian ini adalah analisis persamaan regresi linier berganda. Analisis regresi linier berganda digunakan untuk mencari hubungan atau pengaruh antara variabel independen (Struktur Aktiva, Return On Assets dan Pertumbuhan Penjualan) terhadap struktur modal. Berikut adalah hasil analisis regresi linier berganda:

Tabel 8. Hasil uji analisis linear berganda

\begin{tabular}{lcccc}
\hline & Model & \multicolumn{2}{c}{ Unstandardized Coefficients } & \multicolumn{2}{c}{ Standardized Coefficients } \\
\cline { 3 - 5 } & & B & Std. Error & Beta \\
\hline 1 & (Constant) & 1.262 & 0.136 & -0.279 \\
& SA & -0.641 & 0.201 & -0.039 \\
& ROA & -0.394 & 0.910 & -0.022 \\
\hline & PP & -0.018 & 0.074 & \\
\multicolumn{2}{l}{ a. Dependent Variable: SM } & & &
\end{tabular}

Sumber : Hasil data yang diolah (SPSS 2018) 
Berdasarkan Tabel 8 pada kolom Unstandardized Coefficients bagian B didapatkan model persamaan linier berganda sebagai berikut :

$$
\mathrm{SM}=1.262-6.41 \mathrm{SA}-3.94 \mathrm{ROA}-0.18 \mathrm{PP}
$$

Persamaan regresi dapat diinterpretasi sebagai berikut ini:

1. Konstanta a sebesar 1.262 menyatakan bahwa jika variabel Struktur Aktiva, Return On Assets dan Pertumbuhan Penjualan nilainya adalah 0, maka Struktur Modal sebesar 1.262.

2. Koefisien $b_{1}$ sebesar -0.641 menyatakan bahwa jika terjadi peningkatan setiap satuan variabel Struktur Aktiva maka struktur modal akan mengalami penurunan sebesar 0.641.

3. Koefisien $b_{2}$ sebesar -0.394 menyatakan bahwa jika terjadi peningkatan setiap satuan terhadap variabel Return On Assets, maka struktur akan mengalami penurunan sebesar 0.394 .

4. Koefisien $b_{3}$ sebesar -0.018 menyatakan bahwa jika terjadi peningkatan setiap satuan terhadap variabel pertumbuhan penjualan, maka struktur modal akan mengalami penurunan sebesar 0.018

Koefisien Determinasi Hipotesis. Tujuan dilakukannya Koefisien determinasi untuk melihat sejauh mana keseluruhan variabel independen menjelaskan variabel dependen.. Bila $\mathrm{R}^{2}=0$, menunjukan bahwa variasi variabel independen yang digunakankan dalam tidak menjelaskan variabel independen. Jika $\mathrm{R}^{2}=1$, maka variabel independen menjelaskan variabel dependen. Berikut ini adalah hasil perhitungan:

Tabel 9. Uji Koefisien Determinasi

$\begin{array}{llll}\text { Model } & \text { R Square } & \text { Adjusted R Square } & \text { Std. Error of the Estimate }\end{array}$

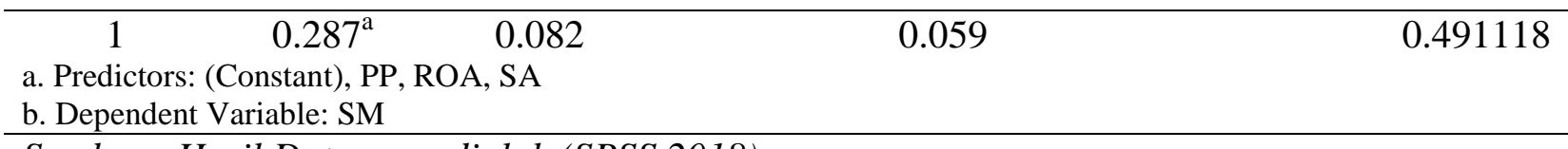

Sumber : Hasil Data yang diolah (SPSS 2018)

Tabel 9 menunjukkan hasil analisa regresi dapat dilihat secara keseluruhan. Nilai Adjusted $R$ Square sebesar 0.059. Hal ini menunjukkan bahwa 5,9\% variasi variabel Struktur Modal (Y) dapat dijelaskan oleh variasi variabel Struktur Aktiva $\left(\mathrm{X}_{1}\right)$, Return on Assets $\left(\mathrm{X}_{2}\right)$ dan Pertumbuhan Penjualan $\left(\mathrm{X}_{3}\right)$.

Hipotesis Secara Parsial. Uji t adalah pengujian yang dilakukan secara per variabel $\mathrm{X}$ terhadap $\mathrm{Y}$ dengan patokan $\mathrm{H}_{0}$ diterima dan $\mathrm{H}_{1}$ ditolak jika $\mathrm{t}_{\text {hitung }}<\mathrm{t}_{\text {tabel }}$ dengan signifikan $>$ 0,05. Dalam hal ini, $\mathrm{H}_{\mathrm{a}}$ diterima dan $\mathrm{H}_{0}$ ditolak jika $\mathrm{t}_{\text {hitung }}>\mathrm{t}_{\text {tabel }}$ dengan signifikan $<0,05$.

Tabel 10. Uji Parsial

\begin{tabular}{|c|c|c|c|}
\hline \multirow[t]{2}{*}{ Model } & Standardized Coefficients & \multirow[t]{2}{*}{$\mathbf{t}$} & \multirow[t]{2}{*}{ Sig. } \\
\hline & Beta & & \\
\hline $\begin{array}{ll}1 & \text { (Constant) }\end{array}$ & & 9.266 & 0.000 \\
\hline SA & -0.279 & -3.186 & 0.002 \\
\hline ROA & -0.039 & -0.433 & 0.666 \\
\hline $\mathrm{PP}$ & -0.022 & -0.239 & 0.811 \\
\hline
\end{tabular}

Sumber: hasil data yang diolah, 2018 
Berdasarkan Tabel 10, menunjukkan bahwa:

1. Hasil uji $\mathrm{t}$ (parsial) struktur aktiva diperoleh nilai thitung $=-3.186$ dan signifikan 0.002 dengan nilai ttabel sebesar 1.65754. jika thitung > ttabel $(3.186>1.65754)$ dan nilai signifikan $(0.002<0.05)$, maka dengan demikian hasil penelitian menolak Ho dan menerima $\mathrm{H} 1$ yang berarti struktur aktiva berpengaruh negatif dan signifikan terhadap struktur modal.

2. Hasil uji t (parsial) return on assets diperoleh nilai thitung $=-0.433$ dan sig 0.666 dengan nilai ttabel diperoleh 1.65754. jika thitung < ttabel $(0.433<1.65754)$ dan nilai signifikan (0.666>0.05), maka demikian hasil menolak H1 dan menerima Ho yang berarti return on assets tidak memiliki pengaruh dan tidak signifikan terhadap struktur modal.

3. Hasil uji $\mathrm{t}$ (parsial) pertumbuhan penjualan diperoleh nilai thitung $=-0.239$ dan signifikan 0.811 dengan nilai ttabel diperoleh 1.65754 . jika nilai thitung < ttabel $(0.239<1.65754)$ dan nilai sig $(0.811>0.05)$ sehingga hasilnya menolak $\mathrm{H} 1$ dan menerima Ho yang memiliki arti tidak memiliki pengaruh dan tidak signifikan terhadap struktur modal.

Pengujian Hipotesis Secara Simultan (Uji F). Untuk membuktikan seberapa jauh ikatan satu variabel X dengan Y secara besama. Dalam uji ini digunakan hipotesis berikut ini Dalam uji F ini digunakan hipotesis yang disebutkan dibawah ini:

Tabel 11. Uji Simultan

\begin{tabular}{llrrrrr}
\hline & Model & Sum of Squares & \multicolumn{1}{c}{ df } & Mean Square & F & Sig. \\
\hline 1 & Regression & 2.611 & 3 & 0.870 & 3.608 & $0.015^{\mathrm{a}}$ \\
& Residual & 29.185 & 121 & 0.241 & & \\
$\quad$ Total & 31.796 & 124 & & & \\
a. Predictors: (Constant), PP, ROA, SA & & & & & \\
b. Dependent Variable: SM & & & & & & \\
\hline
\end{tabular}

Sumber : hasil data yang diolah, 2018

Berdasarkan Tabel 11, menunjukkan nilai-nilai statistik dimana Fhitung sebesar 3.754 dan Ftabel sebesar 2.68. Jika nilai Fhitung > Ftabel sebesar $3.608>2.68$ maka Ho ditolak dan H1 diterima dengan nilai signifikan 0.015 lebih kecil dari 0.05 yang berarti struktur aktiva, return on assets dan pertumbuhan penjualan memiliki pengaruh positif terhadap struktur modal

\subsection{Pembahasan}

Struktur Aktiva berpengaruh negatif dan signifikan terhadap Struktur Modal pada perusahaan property dan real estate di Bursa Efek Indonesia tahun 2011-2015. Return On Assets dan Pertumbuhan Penjualan tidak memiliki pengaruh dan tidak signifikan terhadap Struktur Modal pada perusahaan property dan real estate di Bursa Efek Indonesia tahun 2011-2015. Struktur Aktiva, Return On Assets dan Pertumbuhan Penjualan mempunyai pengaruh dan signifikan terhadap Struktur Modal di perusahaan property dan real estate di Bursa Efek Indonesia tahun 2011-2015.

\section{KESIMPULAN DAN SARAN}

\subsection{Kesimpulan}

Berdasarkan hasil pengujian hipotesis yang dilakukan dengan menggunakan alat SPSS, didapatkan kesimpulan berikut:

1. Struktur Aktiva berpengaruh negatif dan signifikan terhadap Struktur Modal di perusahaan property dan real estate di Bursa Efek Indonesia tahun 2011-2015 dengan nilai signifikan sebesar 0,002 .

2. Return on Assets (ROA) tidak mempunyai pengaruh dengan Struktur Modal di perusahaan property dan real estate di BEI tahun 2011-2015 dengan nilai signifikan sebesar 0,666 . 
3. Pertumbuhan Penjualan tidak memiliki pengaruh dengan Struktur Modal di perusahaan property dan real estate di BEI tahun 2011-2015 dengan nilai signifikan sebesar 0,811.

4. Struktur Aktiva, Return On Assets dan Pertumbuhan Penjualan mempunyai pengaruh terhadap Struktur Modal di perusahaan property dan real estate di BEI tahun 2011-2015 dengan koefisien determinasi sebesar $8,2 \%$

\subsection{Saran}

Berdasarkan hasil penelitian yang telah dilakukan oleh peneliti, saran-saran yang dapat diberikan oleh peneliti adalah sebagai berikut:

1. Bagi Perusahaan Property Real Estate di BEI agar lebih memperhatikan nilai Struktur Modal perusahaan dengan memperhitungkan permintaan pasar secara real karena pada saat ini situasi perekonomian Indonesia tidak stabil dan akan mempengaruhi resiko bisnis.

2. Bagi Universitas Prima Indonesia agar penelitian ini dapat digunakan sebagai wahana pembelajaran dan sebagai gambaran tentang teori akuntansi yang dipelajari mahasiswa.

3. Bagi Peneliti selanjutnya yang tertarik untuk melakukan penelitian sejenis, dapat menambahkan variabel penelitian seperti pajak, pengendalian, sikap manajemen, stabilitas penjualan atau dengan mengganti sektor perusahaan yang diteliti

\section{DAFTAR PUSTAKA}

Atmaja, Lukas Setia. 2008. Teori dan Praktik Manajemen Keuangan. Ed. 1, Yogyakarta: CV. Andi Offest

Ghozali, Imam. 2016. Aplikasi Analisis Multivariete dengan Program IBM SPSS 23, Cetakan

Kedelapan, Semarang: Badan Penerbit Universitas Diponegoro

Harahap, Sofyan Safri. 2015. Analisis Kritis Atas laporan Keuangan. Edisi 1, Cetakan 12, Jakarta: PT RajaGrafindo Persada.

Hery. 2015. Pengantar Akuntansi Comprehensive Edition. Jakarta: PT. Grasindo

Hery. 2015. Analisis Laporan Keuangan Pendekatan Rasio Keuangan. Cetakan 1, Yogyakarta: CAPS (Center for Academic Publishing Service

Jumingan. 2014. Analisis Laporan Keuangan. Cetakan Kelima, Jakarta: PT Bumi Aksara

Kamaludin dan Rini Indriani. 2011. Manajemen Keuangan "Konsep Dasar dan Penerapannya". Edisi Revisi, Bandung: Mandar Maju

Kasmir. 2012. Analisis Laporan Keuangan. Ed. 5, Bandung: PT Rajagrafindo Persada

Prastowo, Dwi. 2014. Analisis Laporan Keuangan Konsep dan Aplikasi. Edisi Ketiga, Cetakan Kedua, Yogyakarta: Unit Penerbit dan Percetakan Sekolah Tinggi Ilmu Manajemen YKPN

Sartono, R. Agus. 2012. Manajemen Keuangan Teori dan Aplikasi. Edisi 4, Cetakan Keenam, Yogyakarta: BPFE-Yogyakarta

Riyanto, Bambang. 2008. Dasar-Dasar Pembelanjaan Perusahaan. Edisi 4, Cetakan Kedelapan, Yogyakarta: BPFE-Yogyakarta

Rodoni, Ahmad dan Herni Ali. 2014. Manajemen Keuangan Modern. Jakarta: Mitra Wacana Media

Sitanggang, J.P. 2013. Manajemen Keuangan Perusahaan Lanjutan Dilengkapi Soal dan Penyelesaian. Edisi Pertama, Jakarta: Mitra Wacana Media

Sugiyono. 2010. Metode Penelitian Bisnis (Pendekatan Kuantitatif, Kualitatif, dan R\&D). Cetakan ke-15, Bandung: CV. Penerbit Alfabeta

Syamsuddin, Lukman. 2011. Manajemen Keuangan Perusahaan, Konsep Aplikasi dalam: Perencanaan, Pengawasan dan Pengambilan Keputusan. Jakarta: PT Rajagrafindo Persada. 